\title{
ÇOCUKLARDA ATEŞLİ DÖKÜNTÜLÜ HASTALIKLAR
}

\author{
EVALUATING RASH IN FEBRILE CHILDREN
}

\author{
Muhammet Ali VARKAL, İsmail YILDIZ, Emin ÜNÜVAR*
}

\begin{abstract}
ÖZET
Çocuklarda ateşli döküntülü hastalıklar sık görülür ve önem taşır. Birçoğunda etken virüslerdir ve kendilerini sınırlandıran hastalıklardır. Ancak daha az sıklıkta olan bakteriyel sistemik hastalıklar hayati risk taşır. En riskli hastalık meningokoksemi, bakteriyel sepsis vakalarıdır. Ateşli döküntülü hastalıklarda tanıda en önemli adım klinik muayenedir. Klinik muayene ile birçoğunda doğrudan tanıya gidilebilir. Birçoğu makülopapüler döküntülü hastalıklardır. Ateşli bir çocukta peteşiyal döküntüler aksi ispat edilinceye kadar meningokoksemi bulgusu olarak kabul edilmelidir. Bu grup içinde kızamık, kızamıkçık, kızıl, suçiçeği, eritema enfeksiyozum, roseola infantum, Epstein-Barr virüs enfeksiyonları, sitomegalovirüs (CMV) enfeksiyonları, Kawasaki hastalığı ve ülkemiz için Kırım-Kongo kanamalı ateşi önemlidir.
\end{abstract} Anahtar kelimeler: Ateş;çocuk;döküntü; enfeksiyon.

\begin{abstract}
Fever accompanied by rash is a common complaint in pediatric practice. Mostly these conditions are caused by different viruses and self-limited. But, it may also be the first and only sign of serious and life-threatening bacterial infections, like meningococcemia and bacterial sepsis. The most important step in the diagnostic process is a detailed clinical examination. A detailed physical examination can easily lead the physician to the correct diagnosis. The rash in children is often maculopapular and nonspecific. However a petechial rash should be evaluated as meningococcemia until the contrary is proven. Most common diseases presenting with fever and rash are measles, rubella, scarlet fever, erythema infectiosum, roseola infantum, Epstein-Barr virus infection, cytomegalovirus (CMV) infections, Kawasaki disease and for our country Crimean-Congo hemorrhagic fever.
\end{abstract}

Key words: Fever;child;rash;infection.

\section{GíRIŞ}

Ateşli ve döküntülü bir çocuğun ayırıcı tanısı pediatrinin en sık görülen ve en önemli konularındandır. Çocuklarda viral döküntülü hastalıklar çoğu kez kendisini sınırlandıran, tedavisiz de düzelebilen akut enfeksiyon hastalıklarından oluşur. Temel iki bulgu başlıkta da olduğu gibi ateş ve döküntüdür. Birçoğunda neden virüslerdir. Goodyear ve arkadaşlarının 1991 yılında 100 ateşli, döküntülü çocuğun tanılarının araştırıldığı çalışmasının sonuçlarında 65 vakada enfeksiyon hastalıkları saptanmıştır. Bunlar içinde \%65'ini viral döküntülü hastalıklar, \%20'sini de bakteriyel enfeksiyonlar oluşturmuştur (5). Bu araştırma göstermektedir ki ateşli döküntünün görüldüğü hastalarda en sık neden olarak viral enfeksiyonlar öne çıkmaktadır. Ateşli döküntülü hastalıkların birçoğu kendisini sınırlandırsa da bazıları hayati risk taşır. Meningokoksemi başta olmak üzere bakteriyel sepsis vakalarında da benzer döküntüler olabilir. Diğer yandan, aynı etken farklı bireylerde farklı karakterlerde döküntülere neden olabilmekte, aynı karakterdeki döküntüler de farklı etkenlerden kaynaklı olabilmektedir (Tablo-1) (2, 12). Viral döküntülü, ateşli hastalıkların tanısı hasta için önem taşıdığı gibi, gebeler, immun yetersizlikler başta olmak üzere diğer bireylere olan bulaşma riskleri, toplum sağlığ́ yönünden olası salgın riskleri için de önem taşır. Ateşli ve döküntüleri olan çocuklarda en sık neden enfeksiyon hastalıkları (önde gelen viral, sonra bakteriyel) iken, bunu alerjik, romatolojik, hematolojik hastalıklar izler (Tablo-2) (3, 4). Vakaların çoğunda döküntünün klinik olarak değerlendirilmesi tanı için çoğu kez yeterli iken, enfeksiyon hastalıklarının genel özellikleri mutlaka irdelenmelidir. Enfeksiyon hastalığı olduğu için, öyküde bulaşma kaynağı, kuluçka dönemi, prodromal bulgular, seyahat öyküsü, aşılanma durumu, yaşadığı toplumun özellikleri, kronik bir hastalığı olup olmaması, bağışıklık sisteminde sorun olup olmaması, yakın zamanda hastaneye yatış öyküsü olup olmaması önemlidir (Tablo-3) $(3,4)$.

\footnotetext{
Date received/Dergiye geldiği tarih: 26.02.2015 - Dergiye kabul edildiği tarih: 10.03.2015

* İstanbul Üniversitesi, İstanbul Tıp Fakültesi, Çocuk Sağlığı 1 ve Hastalıkları Anabilim Dalı, İstanbul, TÜRKIYE

(İletişim kurulacak yazar: mavarkal@istanbul.edu.tr)
} 
Tablo-1. Çocuklarda sık görülen döküntüler ve sık nedenleri $(2,12)$.

\begin{tabular}{|c|c|}
\hline Döküntü çeşitleri & Etiyolojileri \\
\hline Makülopapüler döküntüler & $\begin{array}{l}\text { Kızamık, kızamıkçık, kızıl, eritema enfeksiyosum, ekzentema subitum, ilaç } \\
\text { allerjisi, enfeksiyöz mononükleoz, enteroviral enfeksiyonlar, adenoviral } \\
\text { enfeksiyonlar, otoimmün hastalıklar }\end{array}$ \\
\hline Diffüz eritematöz döküntü ve & Kızıl, Steven’s-Johnson sendromu, Kawasaki hastalığı, Streptokokkal veya \\
\hline deride soyulmalar & Stafilokokkal toksik şok sendromu, ilaca bağlı toksik epidermolizis \\
\hline Veziküler döküntüler & $\begin{array}{l}\text { Suçiçeği, herpes virüs enfeksiyonları, enteroviral enfeksiyonlar, Steven's- } \\
\text { Johnson sendromu }\end{array}$ \\
\hline $\begin{array}{l}\text { Peteşiyal, purpurik döküntüler } \\
\text { (ACİL!) }\end{array}$ & $\begin{array}{l}\text { Meningokoksemi, Riketsiyal hastalıklar, Kırım Kongo kanamalı ateşi, } \\
\text { vaskülitler }\end{array}$ \\
\hline
\end{tabular}

Tablo-2. Ateşli ve döküntüsü olan çocukta ayırıcı tanıda en sık görülen hastalıklar $(3,4)$.

Enfeksiyon hastalıkları

Viral enfeksiyonlar Kıamık, kızamıkçık, su çiçeği, ADV, HHV-1, HHV-2, HHV-6, HHV-7, Parvovirus B-19, EBV, CMV, Kırım Kongo kanamalı ateşi virüsü, Coxsackie virüsler

Bakteriyel enfeksiyonlar

S. aureus, A grubu $\beta$-hemolitik streptokok, Neisseria meningitidis, Salmonella typhi

Riketsial hastalıklar

Rickettsia typhi, Coxiella burnetti

Enfeksiyon dışı nedenler

Kollajen doku (difüz bağ dokusu) hastalıkları

Sistemik Lupus Eritematozus (SLE), sistemik form juvenil idiopatik artrit, makrofaj aktivasyon sendromu, dermatomiyozit, Kawasaki hastalığı, HenochSchönlein purpurası, poliarteritis nodosa

İlaç döküntüleri

Steven's-Johnson sendromu, toksik epidermal nekrolizis, DRESS sendromu, lökositoklastik vaskülit

Tablo-3. Ateşli, döküntülü çocuğun eşlik eden diğer klinik bulgulara göre ayrıcı tanısı $(3,4)$.

\section{Ateşli döküntülü çocukta eşlik eden klinik bulgu}

Üst solunum yolu enfeksiyonu prodromal semptomları

Ani başlayan yüksek ateş

Ateşlin çok şiddetli olmadığı, yavaş yavaş ortaya çıktı̆̆ Miyalji ve/veya küçük eklemlerin poliartriti

Büyük eklemlerin artrit bulguları

Hepatosplenomegali ve/veya lenfadenopati

Şok tablosu, kanamalar

\section{Klinik bulgusuna göre olası tanılar}

Kızamık, kızamıkçık, eritema enfeksiyozum, ekzentema subitum, suçiçeği, adenoviral enfeksiyonlar, coxsackie virus enfeksiyonları, EBV, Kızıl

Kızamık, kızıl, kızamıkçık, enfeksiyöz mononükleoz, eritema enfeksiyozum, ekzentema subitum, coxsackie virus enfeksiyonları, Kawasaki hastalığı, meningokoksemi, akut romatizmal ateş, toksik şok sendromu

SLE, Juvenil dermatomiyozit, poliarteritis nodosa Juvenil idiyopatik artrit, SLE, Juvenil dermatomiyozit Akut romatizmal ateş, Henoch-Schönlein purpurası

Enfeksiyöz mononükleoz, bruselloz, otoimmün hastalıklar

Meningokoksemi, toksik şok sendromu
Viral döküntülü hastalıklarda en sık görülen döküntüler maküler veya makülopapüler döküntülerdir (Tablo-1). Bunu veziküler döküntüler izler. Nodüler, büllöz döküntüler daha geri sırada iken, aciliyeti yönüyle en önemli, atlanmaması gereken döküntüler peteşiyal ve purpurik döküntülerdir. Ateşli bir çocukta peteşiyel veya purpurik döküntüler aksi ispat edilinceye kadar bakteriyel sepsisin bir bulgusu olarak kabul edilmeli ve ona göre yaklaşım yapılmalıdır (7).

Viral makülopapüler döküntüler deri seviyesinde veya deriden hafif kabarık, kırmızı pembe renkte, basmakla solan nitelikte ve kaşıntısızdır. Ateşli bir çocukta makülopapüler döküntüler çoğu kez viral bir hastalığa aittir. Kızamık, kızamıkçık, kızıl, 5 ve 6 . hastalıklar, Kawasaki hastalığı bu tip bir döküntüye neden olur. Meningokoksemide her ne kadar peteşiyal döküntüler hakimse de erken dönemlerinde makülopapüler döküntüler eşlik edebilir.

Veziküler döküntüler, ateşli ve döküntülü çocuklarda ikinci sıklıkta gözlenen döküntülerdir. Veziküllerin sınırları net, büyüklüğü $0,5 \mathrm{~cm}$ den daha küçük, içi berrak bir sıvı ile dolu olan döküntülerdir. Herpes virüslerin neden olduğu enfeksiyonlarda, suçiçeğinde, enteroviral enfeksiyonlarda (koksaki virüs enfeksiyonlarında, el-ayak-ağız hastalığında) görülebilir. Nodüler deri lezyonları daha nadirdir. 
Diseases with rashes

Tablo-4. Çocuklarda sık görülen viral ateşli döküntülü hastalıkların klinik özellikleri $(2,3,4)$.

\begin{tabular}{|c|c|c|c|c|c|c|}
\hline Hastalığın adı & Etiyoloji & Epidemiyoloji & $\begin{array}{l}\text { Döküntünün } \\
\text { karakteri }\end{array}$ & $\begin{array}{l}\text { Tanı } \\
\text { noktaları }\end{array}$ & $\begin{array}{l}\text { Kesin tanı } \\
\text { testi }\end{array}$ & Tedavi \\
\hline Kızamık & Kızamık virüsü & $\begin{array}{l}\text { Bağışık } \\
\text { olmayanlarda } \\
\text { ilk } 9 \text { yılda sık }\end{array}$ & $\begin{array}{l}\text { Baştan } \\
\text { başlayan, } \\
\text { aşağıya } \\
\text { gövdeye ve } \\
\text { ekstremitelere, } \\
\text { yayınlan } \\
\text { kaşıntısız, } \\
\text { birleşme } \\
\text { eğiliminde, } \\
\text { makülopapüler } \\
\text { döküntü }\end{array}$ & $\begin{array}{l}\text { Prodromal } \\
\text { bulguları } \\
\text { vardır, } \\
\text { "coryza", } \\
\text { konjunktivit, } \\
\text { öksürük, } \\
\text { Koplik } \\
\text { lekeleri, 4-5. } \\
\text { gün başlayan } \\
\text { makülopapüler } \\
\text { döküntüler }\end{array}$ & $\begin{array}{l}\text { Seroloji, } \\
\text { kızamık } \\
\text { virüsüne karş1 } \\
\text { gelişmiş IgM } \\
\text { ve IgG } \\
\text { antikoları }\end{array}$ & $\begin{array}{l}\text { Antiviral ilacı } \\
\text { yok } \\
\text { A vitamin } \\
\text { desteği } \\
\text { malnutrisyonu } \\
\text { olanlara ve } 2 \text { yaş } \\
\text { altına verilir }\end{array}$ \\
\hline Kızamıkçık & $\begin{array}{l}\text { Kızamıkçık } \\
\text { virüsü }\end{array}$ & $\begin{array}{l}\text { Bağışık } \\
\text { olmayan } \\
\text { adölesanlar }\end{array}$ & $\begin{array}{l}\text { Makülopapüler, } \\
\text { basmakla solan, } \\
\text { küçük boyutta, } \\
\text { toplam } 3 \text { günde } \\
\text { kaybolur }\end{array}$ & $\begin{array}{l}\text { Prodrom } \\
\text { semptomları } \\
\text { kızamık kadar } \\
\text { belirgin değil, } \\
\text { yumuşak } \\
\text { damakta } \\
\text { peteşiler } \\
\text { (Forscheimer } \\
\text { lekeleri), } \\
\text { konjunktivit, } \\
\text { kırgınlı, artrit }\end{array}$ & $\begin{array}{l}\text { Kızamıkçık } \\
\text { virüsüne karşı } \\
\text { gelişmiş olan } \\
\text { IgM ve IgG } \\
\text { antikorları }\end{array}$ & $\begin{array}{l}\text { Antiviral bir } \\
\text { ilacı yok, } \\
\text { antipiretik } \\
\text { ilaçlar }\end{array}$ \\
\hline $\begin{array}{l}\text { Eritema } \\
\text { enfeksiyozum } \\
\text { (5.hastalık) }\end{array}$ & $\begin{array}{l}\text { Parvovirüs B- } \\
19\end{array}$ & $\begin{array}{l}\text { Okul çağı } \\
\text { çocukları }\end{array}$ & $\begin{array}{l}\text { Yüzde tokat } \\
\text { atılmış el izi } \\
\text { kalmışcasına } \\
\text { bir döküntü, } \\
\text { gövdede ve } \\
\text { ekstremitelerde } \\
\text { retiküler } \\
\text { makülopapüler } \\
\text { döküntüler }\end{array}$ & $\begin{array}{l}\text { Artrit eşlik } \\
\text { edebilir, büyük } \\
\text { eklemleri de } \\
\text { tutabilir, } \\
\text { romatojenik } \\
\text { bir virüstür, } \\
\text { eldiven çorap } \\
\text { tarzında } \\
\text { döküntü } \\
\text { yapabilir, } \\
\text { sıcakla } \\
\text { döküntü artar, } \\
\text { ürtikerle } \\
\text { karıstırıllır, 10- } \\
14 \text { gün } \\
\text { döküntü } \\
\text { sürebilir }\end{array}$ & $\begin{array}{l}\text { Parvovirüs B- } \\
19 \text { 'a karşı } \\
\text { gelişmiş IgM } \\
\text { ve IgG } \\
\text { antikorlar } \\
\text { PCR yöntemi } \\
\text { ile virüsün } \\
\text { araştırılması }\end{array}$ & $\begin{array}{l}\text { Tedavisi yoktur, } \\
\text { semptomatik } \\
\text { davranılır }\end{array}$ \\
\hline $\begin{array}{l}\text { Roseola } \\
\text { infantum (6. } \\
\text { Hastalık) }\end{array}$ & HHV-6 & $\begin{array}{l}6 \text { ay ile } 3 \text { yaş } \\
\text { arasındaki süt } \\
\text { çocukları }\end{array}$ & $\begin{array}{l}\text { Yüzden } \\
\text { başlayan, } \\
\text { özellikle } \\
\text { gövdede olan, } \\
\text { yaygın } \\
\text { basmakla solan, } \\
\text { etrafi hafif } \\
\text { soluk, } \\
\text { makülopapüler } \\
\text { döküntü }\end{array}$ & $\begin{array}{l}\text { Döküntü } \\
\text { genelde ateşin } \\
\text { düşmesini } \\
\text { takiben ortaya } \\
\text { çıar, 1-2 } \\
\text { günde de } \\
\text { kaybolur }\end{array}$ & $\begin{array}{l}\text { Tanısı klinik } \\
\text { bulgulara } \\
\text { dayanır, } \\
\text { nadiren viral } \\
\text { serolojik } \\
\text { testler gerekir }\end{array}$ & $\begin{array}{l}\text { Tedavisi } \\
\text { semptomatiktir, } \\
\text { antipiretikler } \\
\text { kullanılır }\end{array}$ \\
\hline Meningokoksemi & $\begin{array}{l}\mathrm{N} . \\
\text { menengitidis }\end{array}$ & $\begin{array}{l}\text { Ülkemizde <5 } \\
\text { yaş }\end{array}$ & $\begin{array}{l}\text { Peteşiyal, } \\
\text { purpurik } \\
\text { döküntüler, } \\
\text { gövdede veya } \\
\text { ekstremitelerde }\end{array}$ & $\begin{array}{l}\text { Ani başlar, } \\
\text { hızlı seyreder, } \\
\text { ateş yüksektir, } \\
\text { şok tablosu, } \\
\text { Damar içi } \\
\text { yaygın } \\
\text { pıhtılaşma } \\
\text { (DİC) eşlik } \\
\text { eder, ağır } \\
\text { lökositoz, } \\
\text { yüksek CRP, } \\
\text { nötrofili, \%50 } \\
\text { vakada } \\
\text { menenjit } \\
\text { bulguları }\end{array}$ & $\begin{array}{l}\text { Klinik } \\
\text { bulgular ve } \\
\text { hemokültürden } \\
\text { bakterinin } \\
\text { izolasyonu, } \\
\text { PCR } \\
\text { yöntemleri }\end{array}$ & $\begin{array}{l}\text { En erken } \\
\text { dönemde yüksek } \\
\text { doz IV } \\
\text { antibiyotik } \\
\text { (seftriakson } \\
\text { veya } \\
\text { sefotaksim), İV } \\
\text { sıvı desteği, DİC } \\
\text { tedavisi }\end{array}$ \\
\hline
\end{tabular}




\begin{tabular}{|c|c|c|c|c|c|c|}
\hline Kızıl & $\begin{array}{l}\text { S. pyogenes ( } \\
\text { A grubu } \beta \text { - } \\
\text { hemolitik } \\
\text { streptokok) }\end{array}$ & $\begin{array}{l}\text { Çocuk yaş } \\
\text { grubu, } \\
\text { özellikle <5 } \\
\text { yaş }\end{array}$ & $\begin{array}{l}\text { Nokta } \\
\text { büyüklüğünde } \\
\text { yaygın } \\
\text { makülopapüler } \\
\text { döküntüler, } \\
\text { basmakla solar, } \\
\text { ağız çevresi } \\
\text { soluktur, tavuk } \\
\text { derisi } \\
\text { görüntüsü } \\
\text { vardır }\end{array}$ & $\begin{array}{l}\text { Tonsillit veya } \\
\text { deri } \\
\text { enfeksiyonu } \\
\text { vardır, Pastia } \\
\text { çizgileri } \\
\text { görülebilir, } \\
\text { çilek dili } \\
\text { bulgusu vardır, } \\
\text { döküntü } \\
\text { sonrasında } \\
\text { parmak } \\
\text { derisinde } \\
\text { soyulmalar } \\
\text { gözlenir }\end{array}$ & $\begin{array}{l}\text { Hizlı } \\
\text { streptokok } \\
\text { testleri, boğaz } \\
\text { kültürü veya } \\
\text { enfekte } \\
\text { deriden alınan } \\
\text { materyelin } \\
\text { kültürü }\end{array}$ & $\begin{array}{l}\text { Tedavisinde } \\
\text { penisilin, } \\
\text { amoksisilin } \\
\text { kullanilabilir. } \\
\text { Alerji öyküsü } \\
\text { varsa } \\
\text { sefalosporinler } \\
\text { veya } \\
\text { makrolidler } \\
\text { kullanılır }\end{array}$ \\
\hline Suçiçeği & $\begin{array}{l}\text { Varicella } \\
\text { Zoster virus }\end{array}$ & $\begin{array}{l}\text { Bağışık } \\
\text { olmayanlarda } \\
<10 \text { yaş }\end{array}$ & $\begin{array}{l}\text { Önce kısa } \\
\text { sureli } \\
\text { makülopapüller } \\
\text { olarak başlar, } \\
\text { sonra etrafi } \\
\text { eritemli, içi } \\
\text { berrak sıvı ile } \\
\text { dolu veziküller } \\
\text { belirir, yüzde, } \\
\text { saçlı deride, } \\
\text { gövdede olur, } \\
\text { kaşıntılidır, } \\
\text { polimorfizm } \\
\text { gösterir }\end{array}$ & $\begin{array}{l}\text { Prodromal } \\
\text { dönem } \\
\text { bulguları } \\
\text { vardır, } \\
\text { döküntüler } \\
\text { mukozalarda, } \\
\text { konjunktivada } \\
\text { olabilir }\end{array}$ & $\begin{array}{l}\text { Tanısı klinikle } \\
\text { konulur, Tzank } \\
\text { yayması } \\
\text { pozitiftir, } \\
\text { şüpheli } \\
\text { vakalarda IgM } \\
\text { ve IgG } \\
\text { bakılabilir }\end{array}$ & $\begin{array}{l}\text { İmmün sistemi } \\
\text { sağlıklı } \\
\text { olanlarda } \\
\text { semptomatik } \\
\text { tedavidir, ağır } \\
\text { vakalarda, } \\
\text { immün } \\
\text { yetersizliklilerde } \\
\text { asiklovir } \\
\text { kullanılabilir, } \\
\text { asla aspirin } \\
\text { verilmez }\end{array}$ \\
\hline $\begin{array}{l}\text { Kawasaki } \\
\text { hastalığı }\end{array}$ & $\begin{array}{l}\text { Kesin nedeni } \\
\text { belli değil. } \\
\text { Streptokokların } \\
\text { süperantijen } \\
\text { teorisi? }\end{array}$ & $\begin{array}{l}\text { Özellikle }<5 \\
\text { yaş, } \\
\text { erkeklerde } \\
\text { daha s1k }\end{array}$ & $\begin{array}{l}\text { Dudaklar şiş, } \\
\text { ödemli, çatlak, } \\
\text { çocuk } \\
\text { huzursuz, kızıl } \\
\text { veya kızamık } \\
\text { benzeri bir } \\
\text { döküntü, } \\
\text { makülopapüler } \\
\text { karakterde, } \\
\text { kaşıntısız, } \\
\text { gövdede veya } \\
\text { perine } \\
\text { bölgesinde } \\
\text { olabilir }\end{array}$ & $\begin{array}{l}\text { Yüksek ateş, } \\
\text { servikal } \\
\text { lenfadenopati, } \\
\text { el ve ayak } \\
\text { parmaklarında } \\
\text { ödem, BCG } \\
\text { izinde eritem, } \\
\text { çilek dili } \\
\text { bulgusu, } \\
\text { bilateral } \\
\text { pürülan } \\
\text { olmayan } \\
\text { konjunktivit, } \\
\text { miyalji, artrit } \\
\text { ve koroner } \\
\text { arterlerin } \\
\text { tutulumu, } \\
\text { anevrizmalar }\end{array}$ & $\begin{array}{l}\text { Tanısı klinik } \\
\text { bulgularla } \\
\text { konulur, } \\
\text { spesifik tanı } \\
\text { kriterleri } \\
\text { kullanılır, } \\
\text { lökositoz, } \\
\text { yüksek CRP, } \\
\text { piyüri, yüksek } \\
\text { AST, ALT, } \\
\text { düşük serum } \\
\text { albumin } \\
\text { gözlenir }\end{array}$ & $\begin{array}{l}\text { Yüksek doz (2 } \\
\text { gr } / \mathrm{kg} \text { ) IVIG, } \\
\text { aspirin }\end{array}$ \\
\hline $\begin{array}{l}\text { Toksik şok } \\
\text { sendromu }\end{array}$ & $\begin{array}{l}\text { S. aureus, } \\
\text { S. pyogenes }\end{array}$ & $\begin{array}{l}\text { Her yaş } \\
\text { grubunda } \\
\text { görülebilir }\end{array}$ & $\begin{array}{l}\text { Diffüz, güneş } \\
\text { yanığı gibi } \\
\text { eritem, maküler } \\
\text { döküntü, } \\
\text { döküntüden 1-2 } \\
\text { hafta sonara } \\
\text { gelişen derideki } \\
\text { soyulmalar }\end{array}$ & $\begin{array}{l}\text { Yüksek ateş, } \\
\text { hipotansiyon, } \\
\text { şok tablosu, } \\
\text { lokalize bir } \\
\text { enfeksiyon } \\
\text { odağı }\end{array}$ & $\begin{array}{l}\text { Klinik tanı } \\
\text { kriterleri, } \\
\text { dokudan } \\
\text { bakterinin } \\
\text { izolasyonu } \\
\text { veya toksin } \\
\text { araştırılması }\end{array}$ & $\begin{array}{l}\text { İV antibiyotik } \\
\text { tedavisi, İV sıv1 } \\
\text { desteği } \\
\text { sağlanması }\end{array}$ \\
\hline
\end{tabular}

Papülden farkı derinin alt kısımlarına kadar uzanabilmesidir. Nodüllerin sınırları kesin değildir. Nodüller daha çok romatolojik hastalıklarda, kronik granülomatöz enfeksiyonlar sırasında görülebilir. En tipik ve nispeten sık görülen örneği eritema nodosumdur. Tibia ön bölgesinde, ağrılı, morumtırak renkte olan, kronik granülomatöz hastalıkların (tüberküloz, sarkoidoz, streptokok enfeksiyonları vb.) tetiklediği bir lezyondur. İçi irin, püy dolu olan püstüller, büller, ya da plaklar daha geri planda olan nadir döküntü tipleridir. Püstüller çoğu kez derinin bakteriyel enfeksiyonları ile gelişir $(3,4)$.

Ateşli ve döküntülü çocuğa neden olan viral enfeksiyonlar insanlık tarihinin kronolojisi ile tanımlanmıştır $(3,7)$. Bugün dünyadan eradike edilen, geçmiş yüzyılların ise en sık görülen korkulanı çiçek hastalığıdır. Bu ilk bilinen döküntülü hastalıktan sonra tanımlananlar tarih diliminde tanımlanma zamanları göz önüne alınarak sıralanmıştır. Çiçek hastalığından sonra sırada kızamık (1. Hastalık, Rubeola ) gelir. Bunu kızıl (2. Hastalık), kızamıkçık (Rubella, 3 gün kızamı̆̆ı, 
Alman Kızamığı, 3. hastalık), 5. Hastalık (Eritema infeksiyosum, Parvovirüs B-19), 6. Hastallk (Human Herpes Virus tip-6, roseola infantum) izler. Siralamada 4. sıra geçmişte "Duke hastalığı" olarak tanımlanmışsa da günümüzde geçerliliği kabul edilmemektedir; özel bir etkeni de gösterilememiştir. $\mathrm{Bu}$ nedenle 4. sira boştur (Tablo-2).

Kızamık: Diğer adı Rubeola'dır. Kızamık virüsü paramiksoviridae ailesinden, morbilivirüs genusundan RNA'lı bir virüstür. Tek bir serotipi vardır. Bu nedenle hastalık geçirilince hayat boyu bağışıklık bırakır. Sadece insanda enfeksiyon yapar. Enfekte olan kişiden bulaşır. Bulaşma kaynağı sadece hasta insanlardır. En kolay bulaşabilen virüslerden birisidir. Eskilerin kap1 deliğinden bulaşan, göz göze gelseniz dahi bulaşır dediği hastalıktır. Damlacıkla virüs havada 1 saat kadar kalabilir. $\mathrm{Bu}$ nedenle temas olmasa da bulaşma riski vardır. Hastalık nadir olarak konjunktivadan veya kan yoluyla da bulaşabilir. Enfeksiyon zincirinin kırılması için toplumda aşılanma oranının \%90'ın üzerine çıkarılması gerekir. Aşılı toplumlarda anneden geçen antikorlar bebeği ilk 6 ay hastalıktan korur. İlk 6 aydan sonra kızamığa karşı olan koruyuculuk azalır.

Patogenezinde virüs temelde solunum sistemini tutar. Mukosiliyer yapıyı bozar ve lokal savunma mekanizmalarını bloke eder. Lenfoid dokuda WarthinFinkeldey dev hücreleri ortaya çıkar. Enfekte hücrelerin bir birleriyle füzyonu sonucu ortaya çıkan dev hücrelerdir. İntrasitoplazmik, intranükleer vakuol oluşumu görülebilir. Solunum yolu epitelinin sinerjisi kaybolur, nötrofiller dahil lokal defans mekanizması çöker. $\mathrm{Bu}$ ilk tutulum noktasından sonra hematojen yayılımla lenforetiküler sistemi tutar (ikinci viremi dönemi). Lenfoid sistem tutulumunda immün sistemi baskılar, T lenfositleri (özellikle CD4) enfekte ederek bağışıklığı zayıflatır. İmmün süpresyon yapabilen bir etkendir. Virüs bu dönemde vücudun birçok farklı dokusuna gidebilir, merkezi sinir sistemini dahi tutabilir.

Klinik bulgularında ise kuluçka dönemi 10-12 gün aralığındadır. Kuluçka döneminde viremi gerçekleşir. $\mathrm{Bu}$ dönemin sonunda klinik bulgular başlar. İlk çıkan semptomlar prodromal dönemi (döküntü öncesi dönem) oluşturur. Prodromal dönem 3-5 gün kadar sürer. Bu dönemin karakteristik bulgularında yüksek ateş, halsizlik, öksürük, burun akıntısı, konjunktivit, lenfadenopatiler eşlik eder. Kızamık için patognomonik kabul edilen ağız içinde ikinci molar diş hizasında yanak mukozasındaki eritemli zemin üzerinde görülen küçük beyaz renkteki eksüdalar "Koplik lekeleri” ortaya çıkar. Koplik lekeleri her kızamık vakasında gözlenmez. Ancak görülürse tanı koydurucudur. Ateşli, burnu akan, öksüren ve bilateral konjuktiviti olan bir çocuk görüntüsündedir. Ateş ve öksürük önemlidir. Ateş ve öksürük olmadan adeta kızamık olmaz.

Prodromal dönemin sonunda yüksek olan ateş düşme eğilimine girer. Ateş düşmeye başlarken makülopapüler döküntüler başlar. Kızamıkta döküntüler baştan başlar. Alın saç çizgisi, ense saç çizgisi gibi bölgelerden başlar önce yüze, sonra boyuna ve gövdeye; en son olarak da ekstremitelere yayılır. Döküntünün baştan başlayıp ekstremiteleri tutması birkaç günü alabilir. Döküntü karakteristik olarak makülopapülerdir, birleşme eğilimi gösterir ve kaşıntısızdır. Döküntü özellikle gövdede yaygındır. Döküntülerin ekstremitelere ulaşmasıyla ateş kaybolur. Döküntüler de yaklaşık bir hafta kadar kalır ve deride kahverengi bir iz birakarak kaybolur. Döküntülerin kaybolması da oluşmasındaki aynı sıra ile olur. Kızamık, hastalığın prodromal dönemi dahil 10-14 günlük bir seyre sahiptir.

Laboratuvar bulgularında ise lökopeni, lenfopeni, nötropeni, trombositopeni görülür. C-Reaktif Protein (CRP) düzeyi artmamıştır. Serum Retinol Bağlayıcı Protein düzeyi düşer.

Kızamık tanısı klinik bulgularla konulursa da bağışıklamanın yoğun olarak yapıldığı günümüzde serolojik testlerle doğrulanması gerekir. Kızamığın tanısında İmmünglobulin $\mathrm{M}$ (IgM) grubu antikorların pozitif olması veya 4 hafta ara ile alınan iki serum örneğinde İmmünglobulin G (IgG) antikorlarında 4 kat veya daha fazla bir artış tanıda önemlidir. Ayrıca günümüzde polimeraz zincir reaksiyonu (PCR) yöntemi ile de solunum yolu sekresyonunda virüs tanımlanabilir. Hastalık döneminde ortaya çıkan IgM grubu antikorlar bir ay süre ile de yüksek kalabilir.

Ayırıcı tanısında kızamıkçık, 5. hastalık, 6. hastalık, enteroviral hastalıklar, adenovirus enfeksiyonları, ilaç döküntüleri, Epstein-barr virus (EBV) enfeksiyonları yer alır (Tablo-4). Burada atlanmaması gereken özel hastalık Kawasaki hastalığıdır. Klinik bulguları kızamığa benzer, örtüşür. Kawasaki hastalığında da makülopapüler döküntü görülebilir. Kawasaki hastalığında öksürük görülmez, burun akıntısı eşlik etmez. Laboratuvar testlerinde de akut faz reaktanlarında artış vardır.

Kızamığın spesifik bir tedavisi, ilacı yoktur. Tedavi destek tedavisidir. Antipiretikler, hidrasyonun sağlanması, gerekirse solunum desteği verilmesi, sekonder bakteriyel enfeksiyonlar varsa antibiyotik tedavisi uygulanır. Özellikle malnütrisyonu olan vakalarda A vitamin desteği verilmelidir.

Kızamığın komplikasyonları önemlidir. Yaklaşık \%1030 oranında gözlenir. Yaş ne kadar küçükse önem o kadar artar. Önde gelenleri sekonder bakteriyel pnömoniler, akut orta kulak iltihabı ve merkez sinir sisteminin tutulmasıdır. Sekonder bakteriyel pnömoniler gram pozitif bakterilerle gelişir. Streptococcus pneumoniae, Staphylococcus aureus önde gelen ajanlardır. Kızamık anerjizan bir enfeksiyon hastalığ olduğundan tüberkülozun reaktivasyonuna yol açabilir. Daha nadir olarak miyokardit, bronşiolitis obliterans, apandisit, laringotrakeobronşit, Guillain-Barre sendromu, İdyopatik Trombositopenik Purpura (ITP)'ya neden olabilir. Geç dönemde SSPE (subakut sklerozan panensefalit)'ye neden olabilir.

Primer korunmada temel yol aşılamadır. Günümüzde Kızamık Kızamıkçık Kabakulak (KKK ve MMRMeasles, Mumps and Rubella) aşısı şeklinde uygulanmaktadır. Canlı, atenüe bir virüs aşısıdır. Ulusal aşılama programımızda 12 . ayda ve ilkokul 1. sınıfta, toplam 2 doz halinde uygulanmaktadır. Aşının en güçlü koruma sağladığı dönem 12-15. aylar arasıdır. Ĕger toplumda bir salgın veya salgın riski varsa aşılama daha öne çekilebilir, ek doz yapılabilir. Aşı subkutan olarak 
üst kol bölgesine uygulanır. Aşılamadan sonra koruyuculuk 1-2 hafta içinde başlar. Tek doz düzgün yapılmış bir aşılama hayat boyu korur. Kızamık geçirildiğinde hayat boyu bağışıklık bırakan bir hastalıktır. Aşıya bağlı 4-6 gün sonra ortaya çıkabilen hafif bir makülopapüler döküntü, kırgınlık, geçici trombositopeni, nötropeni görülebilir. Kızamık aşısı kan veya kan ürünleri, İntravenöz İmmünglobulin (İVIG) kullanımından olumsuz etkilenir, aşının bağışıklama gücü düşer. $\mathrm{Bu}$ nedenle IVİG tedavisi ve kan ürünü verilmesi işleminin mümkünse aşılamadan 3 ay sonra yapılması uygun olacaktır. RSV için kullanılan palivizumab kullanımı aşıya bir engel değildir, sorun oluşturmaz. Temas sonrası korunmada ise ilk 72 saat içerisinde KKK aşısının uygulanması yeterlidir. Eğer aşı yapılamıyorsa temas sonrası 6 gün içinde tek doz İVİG verilebilir $(3,4,11)$.

Kızamıkçık (Rubella, Üç gün kızamığı, Alman kıamığı): Togaviridae ailesinden tek sarmallı RNA'lı bir virüstür (Rubivirüs). Is1, ultraviyole ve ortam asiditesine $(\mathrm{pH})$ duyarlı, soğuğa dayanıklı bir virüstür. Sadece insanda enfeksiyon yapar. Küçük çocuklarda enfeksiyonu önemsiz iken gebelerin enfeksiyonunda Konjenital Rubella Sendromu'na yol açabilir. En riskli grup gebelerdir. Hastalık, çoğu kez hastalığı geçirenlerde ciddi sorunlara neden olmazken, toplum sağlığı için önemi konjenital rubella sendromuna neden olmasıdır. Etken enfekte kişiden damlacık yoluyla, fetusa ise transplasental yolla bulaşır. Erken gebelik döneminde konjenital anomali yapma, sekel birakma riski en yüksek olan TORCH (Toxoplasmosis, Other syphilis, varicella-zoster, parvovirus B19), Rubella, Cytomegalovirus (CMV) ve Herpes enfeksiyonları grubu etkenler içinde en sık görülenidir. En riskli dönem gebeliğin ilk 8 haftasıdır. Embriyogenez dönemindeki bir enfeksiyonun malformasyon riski çok yüksektir (\%80-90). Gebeliğin 16. haftasından sonra risk düşer.

Kuluçka süresi: 14-21 gündür. Virüs solunum yolundan bulaştıktan sonra, replike olur ve bölgesel lenf nodlarına yayılır ve daha sonra viremi yapar. Virüsün bulaştırıcılığı enfeksiyondan 10 gün sonra başlar ve döküntüden 2 hafta sonrasına kadar devam eder (yaklaşık 3 hafta). Fakat en bulaştırıcı olduğu dönem döküntüden 5 gün önce ve döküntüden 6 gün sonradır.

Klinik bulgularda prodromal dönemde kataral bulgular vardır ancak kızamığa göre daha hafiftir. Düşük derecede ateş, boğaz ağrısı, konjunktivit, baş ağrısı, halsizlik, iştahsızlık ve lenfadenopati olur. Suboksipital, posterior auriküler ve anterior servikal bölgede lenfadenopati belirgindir (Theodor bulgusu). Oksipitaldeki lenf bezi büyümesi ağrılıdır. Yuva çocuklarında hastalık subklinik olup, ilk bulgu genellikle döküntüdür. Döküntü yüz ve boyundan başlar. Küçük, düzensiz, ayırt edici özelliği olmayan makül şeklindedir. Daha sonra gövdeye yayılır. Döküntü daha çok gövdede olup, küçük toplu iğne baş1 büyüklügünde, birleşme özelliği göstermeyen makülopapüler döküntü şeklindedir. Gövdeden ekstremitelere yayılır ve k1sa sürer, 3 günde deskuamasyon bırakmadan kaybolur. Ateş vardır ancak kızamık kadar yüksek ve dirençli değildir. Döküntülerle birlikte mukozalarda enantemler de görülür. Yumuşak damaktaki, bir kaç adet küçük, hemorajik peteşiler görülebilir. Bunlara Forchheimer lekeleri denir.

Laboratuvar bulgularında lökopeni, lenfopeni, nötropeni ve hafif düzeyde bir trombositopeni görülebilir. Serum CRP değeri yükselmez.

Tanısı klinik olarak konulur. Eğer herhangi bir risk durumu, gebe ile temas gibi bir durum yoksa serolojik teste de gerek yoktur. Ancak gebe ile temas varsa, ya da riskli bir durum söz konusu ise serolojik testler istenmelidir. $\mathrm{Bu}$ testler hem gebede, hem de hasta kişiden istenir. Kızamıkçı̆̆a karşı gelişmiş IgM antikorlarının pozitif olması tanıda değer taşır. Ayrıca kızamıkçı IgG antikorlarının ikinci bir serum örneğinde 4 kat ve üzerindeki artış da önemsenmelidir. PCR yöntemi, viral kültür de araştırma amaçlı yapılabilir.

Ayırıcı tanısında kızamık, parvovirus-B19 enfeksiyonu, 6. hastalık, ilaç döküntüleri, EBV veya CMV enfeksiyonları, Adenovirus enfeksiyonları yer alır.

Gebelerdeki fetal anomaliler dişında ciddi bir komplikasyona neden olmaz. Trombositopeni, artrit, meningoensefalit, miyokardit, periferal polinöropatiye neden olabilir. Fetal enfeksiyonda abortuslar, konjenital katarakt, kalp defektleri, sağırlık, fetal büyüme geriliği, tromobositopeni, neonatal hepatit, deri bulgularına neden olabilir.

Hastalığın özgün bir tedavisi yoktur. Destek tedavileri yapılır. Gebede fetal enfeksiyon varsa bu aile ile birlikte değerlendirilmeli, vaka bazında karar verilmelidir.

Primer korunmada aşısı mevcuttur. KKK içinde yer alan bir etkendir. Sekonder korunmada ise temas sonras 3 gün içinde aşı yapılması teorik olarak koruyucudur. Hasta gerekli durumlarda döküntü başlangıcından sonraki 7 gün izole edilmelidir.

Konjenital rubella sendromlu çocuklar virüsü yaklaşı 1 yıl yayabilir. Gerektiği durumlarda tekrarlayan nazofaringeal ve idrar kültürleri negatif olana kadar temas önlemleri alınmalıdır.

Gebe bir kadında rubella enfeksiyonu geçiren biri ile temas durumunda; en kısa sürede IgG bakılır, pozitif ise gebe anne bağışıktır ve ek bir şey yapılmaz. Negatif ise; 2-3 hafta sonra bir kez daha bakılır. Tekrar negatif gelir ise temastan 6 hafta sonra tekrar örnek alınır ve negatif gelir ise enfekte olmamıştır. İlk testte negatif olup da 2 . ve 3. testte pozitif olan gebelerde akut bir enfeksiyondan bahsedilir ve gebeye riskler anlatılarak karar verilir (8).

Kızıl: Çocuklarda A grubu $\beta$-hemolitik streptokokların (Streptococcus pyogenes) neden olduğu, bu bakterinin emm gen yapısı sayesinde bazı tiplerinin ürettiği eritrojenik toksin kızıl hastalığına neden olur. Her yaşta görülebilirse de çoğunlukla yaş 5 yaş altındadır. Streptokoksik tonsillofarenjit sirasında yaygın makülopapüler döküntülerle karakterizedir. Bazen enfeksiyon kaynağı deri olabilir (cerrahi kızıl). Ateş, yaygın makülopapüler döküntü, ağız çevresinde solukluk (circumoral pallor), ekstremitelerin gövdeye birleştiği bölgelerdeki deride ince kahverengi çizgilenmeler (Pastia çizgileri), çilek dili bulgusu, derinin adeta soyulmuş tavuk derisi görüntüsünde 
olması, makülopapüler döküntülerin basmakla sarımsı renkte solması (negatif dermografizm), konjunktivitin görülmemesi, boğaz ağrısı ve boğazda streptokoksik tonsillit bulgularının eşlik etmesi, servikal lenfadenopati en tipik bulgularıdır. Döküntü 5-7 gün kadar sürer ve sonra kaybolur. Hastalığın iyileşme döneminde el ve ayak parmaklarında tırnak uç kesimlerinden başlayarak deride eksfoliasyon, soyulmalar gözlenir. $\mathrm{Bu}$ klinik bulguları nedeniyle Kawasaki hastalığının ayırıcı tanısında yer alır. Eğer periferik dolaşım bozukluğu eşlik ederse, şok tablosunun eşlik etmesiyle Streptokoksik Toksik Şok Sendromu olarak adlandırılır. Tanısında klinik bulgular yanında boğaz kültürü yarar sağlar. Lökositoz, sola kayma, yüksek CRP düzeyi eşlik edebilir.

Ayırıcı tanısında kızamıkçık, Parvovirüs-B19 enfeksiyonu, Ebstein-Barr enfeksiyonu, ilaç allerjisi, Kawasaki hastalığı yer alır.

Tedavisinde penisilinler ilk seçenektir. Tek doz benzatin penisilin <27 kg $300.000 \mathrm{IU},>27 \mathrm{~kg} 600.000 \mathrm{IU}$, kas içine (İM) uygulanır. Oral yoldan fenoksimetil penisilin de kullanılabilir. Tedavisi 10 gündür. Günümüzde amoksisilin de tedavi seçenekleri arasındadır. Tanısı konulduğunda antibiyotik tedavisi önemlidir. Zira hastalı sonrası akut romatizmal ateş veya post streptokoksik glomerülonefrit gelişebilir. Hastalığın ilk 10 günü içinde tanısı konulur ve tedavisi başlanırsa akut romatizmal ateş engellenir $(7,10)$.

Eritema enfeksiyosum (5. Hastalık, Parvovirus B-19 enfeksiyonu): Parvoviridae ailesi, Erithrovirüs genusundan tek sarmallı DNA'lı küçük bir virüstür. Parvoviruslar hayvanları enfekte ederler. Bunlardan 2 tanesi sadece insanı efekte eder. Bunlar Parvovirus B-19 ve Bocavirus'tur. Parvovirus B-19 sadece insanda hastalık yapar ve tek bir serotipi vardır. Okul çağı çocuklarının hastalığı olup sıklıkla 5-15 yaş arasında görülür. Enfeksiyon sporadik olarak tüm yıl boyunca görülse de sıklıkla kış ve ilkbahar aylarında görülür. Solunum yolundan damlacıklarla veya kan ürünleri ile de bulaşabilir. Transplasental geçişi vardır.

Patogenezinde virüs özellikle kemik iliğinde eritrosit ana prekürsör hücrelerini enfekte eder. Kişinin bu hücrelerinin membranlarında $\mathrm{P}$ antijeni varsa virüs kolaylıkla bu hücreleri enfekte eder. Hipoplastik bir anemiye neden olur. İmmün sistemin virüse karşı geliştirdiği immün yanıt, antijen-antikor kompleksleri hastalığın ikinci haftasında artraljilere neden olur, döküntüler görülür. Çocuklarda en sık neden olduğu klinik tablo eritema enfeksiyozumdur. Genellikle okul çağı çocuklarıdır.

Klinik bulgularında ateş, halsizlik, miyaljiler, özellikle yüzde daha belirgin olan yaygın makülopapüler döküntüler gözlenir (Resim-1). Yüzdeki karakteristik bulgu tokat atılmış gibi olan eritemdir. Kaşıntısızdır. Gövdede, ekstremitelerde de benzer döküntü vardır. Döküntünün kenarları düzensizdir, ortası ise hafif soluktur. Eldiven çorap tarzında da olabilir. Banyo ile, sıcakla döküntüler artabilir. Viral döküntülü hastalıklar içinde döküntüsü en uzun süreli olandır. Döküntü 9-10 gün kadar sürebilir. Akut ürtikerle karıştırılabilir. Servikal veya yaygın lenfadenopati eşlik edebilir. Anemi, artrit, artralji eşlik edebilir. Bu hastalıkta döküntülü olduğu dönem bulaştırıcı değildir. Çocuk yuvasına, okuluna gidebilir. Parvovirus B-19 TORCH grubu etkenleri içinde yer alır. Fetal enfeksiyon ağır anemilere, hidropsa yol açabilir.

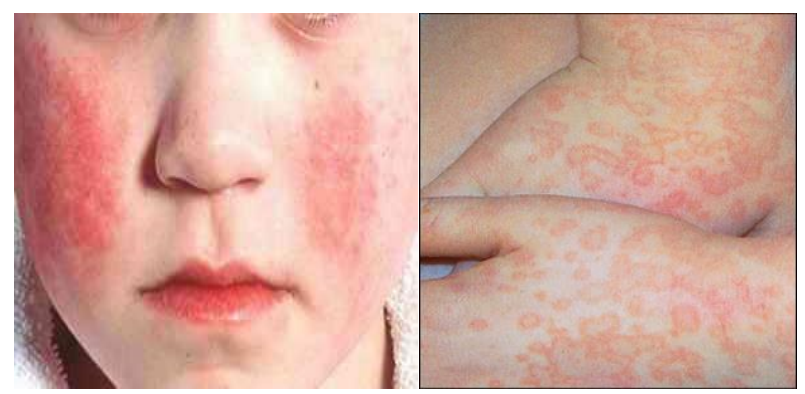

Resim-1: Parvovirus B-19'un neden olduğu eritema enfeksiyosum döküntüleri. Yüzde tokat atılmış tarzda makülopapüler döküntüler, gövedede ise retiküler karakterde, kenarları düzensiz, orta kısmı nispeten soluk makülopapüler döküntüler.

Anemi, nötropeni, lökopeni, trombositopeni, pansitopeni eşlik edebilir. Tanıda etkene karşı gelişen IgM ve IgG grubu antikorlar değer taşır, PCR yöntemi de kullanılabilir.

Ayırıcı tanısında kızamık, kızamıkçık, enteroviral enfeksiyonlar, Kawasaki hastalığı, Ebstein-Barr virus enfeksiyonları, otoimmun hastalıklar, ilaç döküntüleri yer alır.

Tedavisi semptomatiktir. Spesifik bir antiviral ilac1 yoktur $(10,12)$.

Ekzantema subitum (6. Hastalık): İnsan herpes virüslerinden (HHV) beta herpes virüs grubunda yer alan HHV-6 çocukluk dönemine özgü akut, ateşli bir enfeksiyon hastalığıdır. Çocuklara muhtemelen erişkinlerin sekresyonları ile bulaşmaktadır. Vakalar sporadiktir. Salgınlar yapmaz. Toplumda sık gözlenir. Kuluçka dönemi 10-15 gündür. Çocuklarda en s1k 6 ay3 yaş arasında gözlenir. Postnatal ilk 6 ayda gözlenmez. Anneden geçen antikorlar koruyucudur. Bulaştıktan sonra CD4, CD46 T lenfositleri enfekte eder.

Primer HHV-6 enfeksiyonlarında en sık bulgu ateştir. Kısa prodromal dönemi takiben yükselen ateş $\left(40^{\circ} \mathrm{C}\right)$ ve irritabilite vardır. $\mathrm{Bu}$ ateşli dönemde \%5-15 vakada konvülziyon gözlenir. Ateş 3-5 gün sürer ve kriz şeklinde düşer. Ateşin düşmesini takiben 12-24 saat sonra gövdede daha yoğun olan, gül renginde, kaşıntısız, 2-3 $\mathrm{mm}$ büyüklüğünde makülopapüler döküntü olur (Resim-2). Daha sonra döküntü yüze ve ekstremiteye yayılır. Döküntü 1-3 günde geçer. Ek bulgular; irritabilite, inflame timpanik membran, rinore, karın ağrısı ve ensefalopatidir. Öksürük gibi alt solunum sistemi semptomları sık görülmez. Hastalığın ortalama süresi 6 gündür, \%15 olguda 6 günden uzun sürer. Nagayama bulgusu, Asyalı bebeklerde daha sık görülen uvulopalatoglossal bileşkede görülen ülserlerdir.

HHV-6 hayatta tek sefer geçirilir. Nadiren sekonder roseola enfeksiyonu görülebilir ve bu HHV-7'ye bağlıdır.

Laboratuvar bulgularında ortalama lökosit, lenfosit ve nötrofil sayısında düşme, trombositopeni, karaciğer enzimlerinde yükselme, periferik yaymada atipik lenfositler görülebilir. 
Tanıs1 klinik bulgulara dayanır. Gerek duyulan vakalarda kanda PCR yöntemi yardımcıdır.

Ayırıcı tanısında kızamık, kızamıkçık, kızıl, enteroviral enfeksiyonlar ve ilaç döküntüleri yer alır.

Tedavisinde doğrudan kullanılabilen antiviral bir ilaç yoktur. Destek tedavisi verilir, antipiretikler kullanılabilir.

Komplikasyonlarında en önemlisi nörolojik komplikasyonlardır. Febril konvülsiyon hastalığın seyri sırasında gözlenebilir. Ensefalit, aseptik menenjit yapabilir. S1klıkta ise en s1k komplikasyon hastalık sonrasında gözlenen akut orta kulak iltihabıdır $(1,8)$.

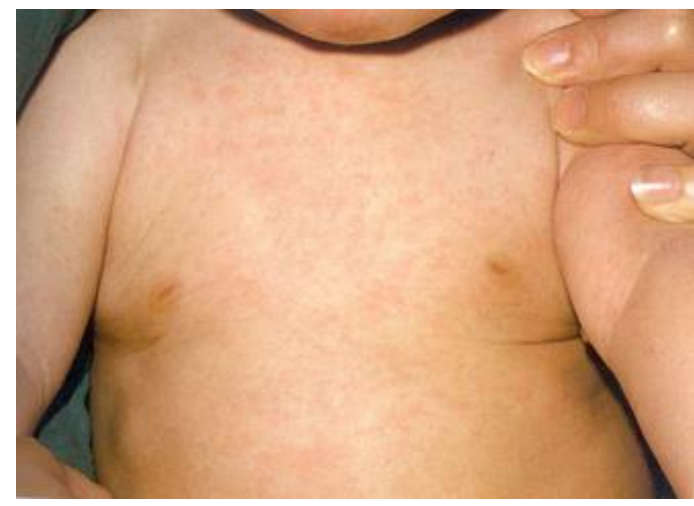

Resim-2: Rozeola infantumun (6.hastallk) gövdede belirgin olan makülopapüler döküntüleri.

Suçiçeği (Varisella): Etken Varisella-Zoster virüs (VZV)'tür. Herpes virüs ailesinde yer alır. Primer, latent veya rekürren enfeksiyon yapar. İntrauterin konjenital enfeksiyona neden olabilir. Primer enfeksiyon daima suçiçeğidir. Latent enfeksiyonun reaktivasyonu Zona'dır. Bu etken sadece insanda enfeksiyon yapar. Primer enfeksiyon sonrasinda servikal, torakal gangliyonlarda gizli kalabilir, immün sistemden kendisini sınırlandırabilir. Yıllar sonra buradan olan reaktivasyon zona olarak karşımıza çıkar.

Suçiçeği asemptomatik geçirilmez. Daima döküntülerle karakterizedir. Bulaştırıcılık döküntüden 7 gün öncesinde başlar, döküntü boyunca da devam eder. En yüksek bulaştırıcılık döküntü öncesi dönemdir. Zona da bulaştırıcıdır, döküntülerinden etken bulaşabilir.

İnkübasyon süresi 10-21 gündür. VZV üst solunum yolu mukozası ve tonsiller lenf dokusuna inoküle olur. Lokal lenf nodlarında virüs replike olduktan sonra subklinik viremi ile retiküloendotelyal sisteme yayılır. Virüs buradan periferik mononükleer hücreler ile taşınarak ikinci viremisini yaparak cilt lezyonlarını oluşturur. İkinci viremi döneminde virüs üst solunum yolu mukozasına ve orofarinkse tekrar yerleştiğinden döküntüden 1-2 gün önce de damlacık yoluyla bulaştırıcılığa neden olur.

Klinik bulgularında polimorfik-kaşıntılı-veziküler döküntülü bir hastalıktır (Resim-3). Prodromal semptomları takiben deride kaşıntılı eritemli makül şeklinde başlayan ve veziküle ilerleyen lezyonlar gözlenir. Döküntü ilk önce saçlı deri, yüz ve gövdede başlar. Döküntüler sentral veya sentripedal yayılım özelliği gösterir. Orofarinks ve vajina gibi mukozalar tutulabilir. Göz kapağında lezyon olabilir ancak ciddi korneal tutulum nadirdir. Lezyonlar ilk aşamada kaşıntılı makül olarak başlar, hızla papül haline gelir, papüllerin içi sıvı dolarak vezikül haline gelir, sonrasında sıvı bulanıklaşır ve göbekleşme gösterir. Her döküntünün farklı evrede olmasına polimorfizm denir. Aynı anda farklı evrede lezyonların olması ve lezyonların gövdede daha yoğun olması suçiçeği için tipiktir. Döküntüler kabuklaşarak 1 haftada iyileşir. Tüm lezyonlar kabuklanana kadar bulaştırıcıdır. Döküntülerden sonra hafif bir hipopigmentasyon birkaç gün veya hafta sürebilir, sekonder enfekte olmadıkça skar olmaz.

Veziküler döküntülü hastalıklar ile ayırıcı tanısı yapılır. Bunlar; herpes simplex, enterovirus, çiçek, riketsiya, $S$. aureus enfeksiyonları, ilaç reaksiyonları, dissemine herpes zoster, kontakt dermatit, böcek 1 sırığıdır. Suçiçeğinin, eradike olan ve biyoterörizm amaçlı kullanılabilecek çiçek ile ayırıcı tanısı yapılmalıdır. Çiçekte tüm lezyonlar aynı evrede ve ekstremitede daha yoğun bulunur ve iz bırakır. Günümüzde veziküler döküntüler gövdede fazla ise suçiçeğini, ekstremitelerde fazla ise el-ayak- ağız hastalığını ayırıcı tanıda düşünmeliyiz.

Suçiçeğine karşı aşılı toplumlarda görülmese de, tek doz aşılı toplumlarda ileri yaş grubu okul çağı çocuklarında toplam döküntü sayısı $<50$ olan çok hafif bir klinikle de görülebilir.

Suçiçeği riskli gruplarda progresyon gösterebilir. Progresif, invazif varisella, yaygın iç organ tutulumu, hemoraji, koagülopati ile karakterize primer varisellanın en korkulan komplikasyonudur. Karaciğer tutulumuna veya mezenterik lenfadenopatiye bağlı ciddi karın ağrısı görülebilir. Gebeler, yenidoğanlar, adölesan ve genç erişkinler, immün yetersizlikler (özellikle hücresel immün yetmezlik, malignite, kanser kemoterapisi alanlar), organ nakli olanlar, yüksek doz sistemik steroid alanlar risk grubunu oluşturur. Uzun süre düşük doz sistemik kortikosteroid kullanımı ciddi varisella için risk faktörü değildir. Ölüm en sık suçiçeği pnömonisine bağlı ilk 3 gün içinde olur. Sağlıklı çocuklarda invazif varisella nadirdir. Suçiçeği virüsü TORCH grubu içinde yer alır ve annedeki primer enfeksiyon konjenital varisellaya neden olabilir. En riskli gebelik dönemi 1722 haftalar arasıdır $(6,10)$.

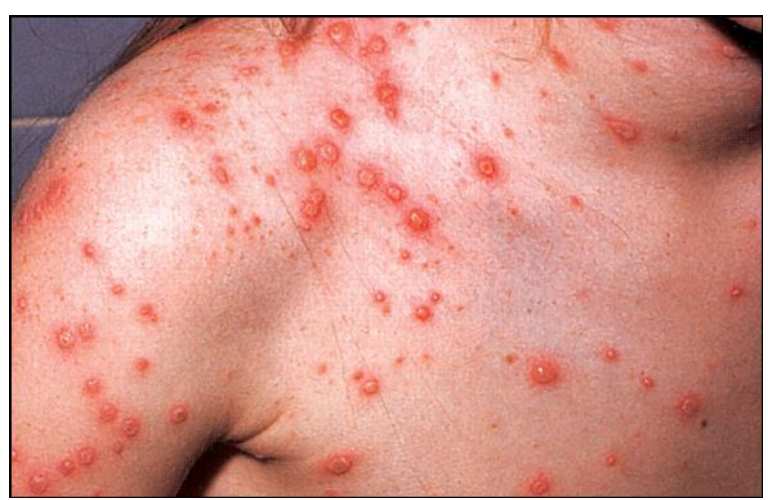

Resim-3: Yaygın suçiçeği döküntüleri. Veziküler karakterde, tipik polimorfizm gösteren, vezikülün içinin berrak bir sıvı ile dolu olduğu, etrafının da eritemli olduğu görülmektedir. 
El-Ayak-Ă̆gı Hastalığı: Çocuklarda coxsackie virüslerin neden olduğu el-ayak-ağı hastalığ 1 da veziküler döküntülere neden olabilen bir hastalıktır. İlkbahar ve yaz döneminde daha sık gözlenir. Tam kesin olmasa da sularla bulaştığı kabul edilmektedir. Kreş çocuklarında daha sık gözlenir. Yüksek ateş, boğazda veziküler döküntüler, el ve ayaklarda makülopapüler, vaziküler döküntülerle karakterizedir (Resim-4). Ateşi 7 gün kadar sürebilir. Gövdede döküntü eşlik etmez. Ancak gluteal bölgede yaygın döküntü görülebilir. Kaşıntısızdır. Veziküllerin hemen hemen hepsi aynı dönemdedir, polimorfik değildir. Miyalji, karın ağrısı, lenfadenopati eşlik edebilir. Hastalığın 2-3. haftasında el parmaklarında daha sık olmak üzere onikolizis gözlenir. Tırnaklar kırılır, ya da yatağından tamamiyle kopar, ayrılır. Tırnak derisinde de soyulmalar eşlik edebilir. Tanısı klinik bulgularla konulur. Tedavisi semptomatiktir. Asiklovir etkisizdir. Hastalığın toplam süresi 2-3 haftadır. Nadiren miyokardit, menenjit, ensefalit yapabilir (1).

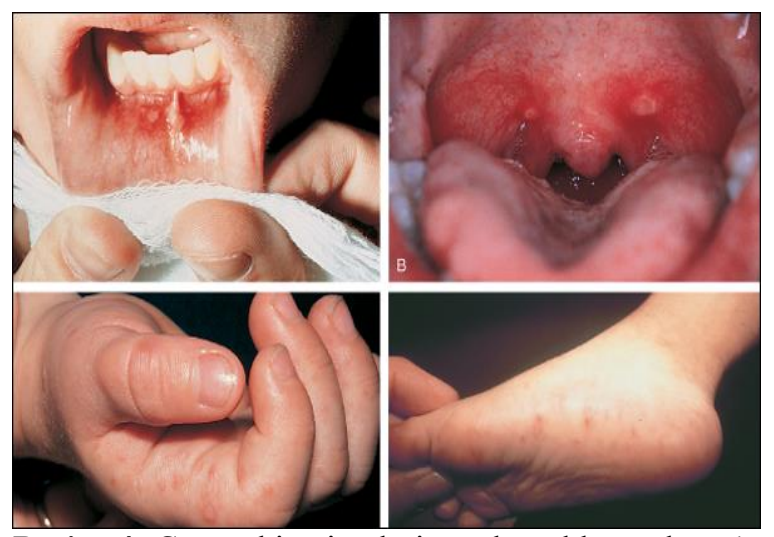

Resim-4: Coxsackie virüslerin neden olduğu el-ayakağız hastalığı. Ağız çevresindeki ülsere lezyonlar, el ve ayakta veziküler döküntü

Epstein-Barr virüs enfeksiyonu (enfeksiyöz mononükleoz): EBV gama herpes virüsü içinde yer alır. Primer enfeksiyonu enfeksiyöz mononükleoz olarak bilinir. Bulaşması enfekte kişinin sekresyonları ile temasla olur. Özellikle de tükürükle olduğu için öpücük hastalığı olarak da bilinir. Kreş çocukları hastalığı genellikle asemptomatik olarak geçirirken, adölesan yaş grubu ise enfeksiyöz mononükleoz tablosunda geçirir. Lenfadenopatileri, yüksek ateş, miyaljileri, splenomegalisi ve eksüdatif tonsilliti tipiktir. Döküntü \%3-5 oranında gözlenir. Döküntünün ilginç özelliği ampisilin başta olmak üzere antibiyotik kullanımını takiben ortaya çıkmasıdır. Gövdede ağırlıklı, yaygın makülopapüler bir döküntüdür. Kesin mekanizması açık değilse de immünolojik bir mekanizma ile döküntü gelişir. Tanısında viral kapsid antijene karşı oluşan EBV-VCA IgM ve IgG'ye bakılabilir. Tedavi gerektirmez kendiliğinden düzelir (1).

CMV: CMV çift sarmal DNA'lı bir herpes virüstür. TORCH grubu içinde yer alır. İmmün sistemi sağlıklı çocuklarda primer enfeksiyonu asemptomatiktir veya enfeksiyöz mononükleoz benzeri bir tablo gözlenir. İmmün baskılanması olanlarda sistemik hastalık tablolarına neden olabilir. EBV benzeri bir döküntü gözlenebilir. CMV enfeksiyonu kanitlananlarda $\mathrm{T}$ hücresel immün yetersizlikler, İnsan Bağışıklık Yetmezlik Virüsü (Human Immunodeficiency Virus, HIV) enfeksiyonları araştırılmalıdır (1,11).

Kawasaki Hastalığı: Çocuklarda Henoch-Schönlein purpurasından sonra en sık görülen vaskülittir. Orta boy arterlerin, özellikle koroner arterlerin tutulumu tipiktir. En az beş gün veya daha fazla süren ateşe, döküntüler eşlik edebilir. Kawasaki hastalığında döküntüler her şekilde olabilir. Sıklıkla makülopapülerdir. Veziküller çok nadirdir. Döküntüler daha sık gövdede gözlenir. Kızamık, kızıl, kızamıkçık döküntüsünü taklit edebilir. Kaşıntısızdır (13).

Meningokoksemi: Ateşli döküntülü hastalıklar içerisinde hekimin asla atlamaması gereken hastalıktır. Döküntüsü peteşiyal, pupurik döküntülerdir (Resim-5). Özellikle uç bölgelerde septik trombüslerdir. Basmakla solmayan, hızla artan purpurik döküntüler tipiktir. Ateşli bir çocukta peteşi, purpurik döküntüler aksi ispat edilinceye kadar meningokoksemi olarak kabul edilmelidir. Purpurik döküntüler sepsis sendromu geliştiğinde ortaya çıkar. Meningokokseminin erken dönemlerinde diğer viral hastalıklarda olduğu gibi makülopapüler döküntüler görülebilir. Şüphe duyulan vakalar acilde izlenmelidir. Hasta yatırılarak hemokültürü alınır ve intravenöz (IV) antibiyotik tedavisine (seftriakson veya sefotaksim) başlanır $(6,7)$.

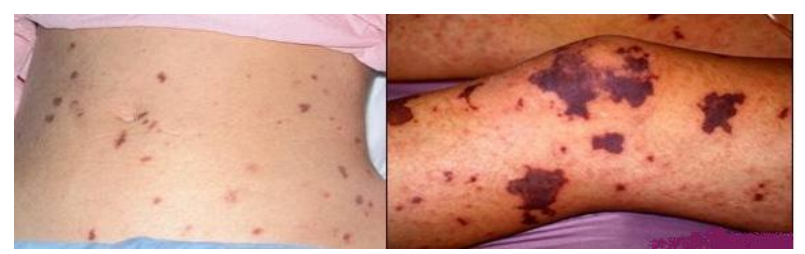

Resim-5: Yaygın purpurik, ekimotik deri lezyonları. Meningokoksemide gelişen yaygın damar içi pıhtılaşma sonucu oluşan gangrenöz, nekrotik dokular.

Kırım-Kongo kanamalı ateşi: Kene 1sırması ile bulaşan ülkemizde de özellikle orta Anadoluda görülen ciddi bir hastalıktır. Viral bir etkenle gelişir. Bunya viridae ailesine ait Kırım Kongo Kanamalı Ateşi virüsüdür. Keneler ana konak, insanlar, vertebralı canlılar, hayvanlar da ara konaktır. Rastlantısal olarak kene 1sırı̆̆ 1 ile bulaşır ve 1sırılan vakaların $1 / 5$ 'inde hastalık gelişmektedir. Prodromal semptomlara yüksek ateş, miyalji ve peteşi, purpurik döküntüler eşlik eder. Ülkemizde meningokoksemi ayırıcı tanisında unutulmamalıdir. Tanisi serolojik testlerle kesinleştirilir. Destek tedavileri uygulanır. Kene ısırmasına karşı önlemler alınmalıdır (9).

Diğer nadir nedenler: Ateşli makülopapüler döküntüleri olan çocuklarda vaskülitler, kollajen doku hastalıkları, Still hastalığı, makrofaj aktivasyon sendromu, maligniteler, histiyositoz sendromları bu döküntülere neden olabilir. Nedeni tam açıklanamamış döküntülerde ateşin yanında olan diğer klinik bulgularla beraber bu hastalıklar da araştırılmalıdır. 


\section{KAYNAKLAR}

1. Biesbroeck L, Sidbury R. Viral exanthems: an update. Dermatol Ther. 2013;26(6):433-8.

2. Dyer JA. Childhood viral exanthems. Pediatr Ann. 2007;36(1):21-9.

3. Ely J, and Stone MS. The generalized rash: Part-I Differentail diagnosis. Am Fam Physician 2010; 81:726-34.

4. Ely J, and Stone MS. The generalized rash: Part-II Differentail diagnosis. Am Fam Physician 2010;81:735-9.

5. Goodyear HM, Laidler PW, Price EH, Kenny PA, Harper JI.Acute infectious erythemas in children: a clinico-microbiological study. $\mathrm{Br} \mathrm{J}$ Dermatol. 1991;124(5):433-8.

6. Gurion R, Sabella C, Zeft AS.Fever and rash in children: important diagnostic considerations. Minerva Pediatr. 2013;65(6):575-85.

7. Mckinnon HD, and Howard T. Evaluating the febrile patient with rash. Am Fam Physician 2000;62:80416.

8. Mancinci A. Exanthems in childhood: An update. Pediatr Ann 1998;27:163-70.

9. Oncü S. Crimean-Congo hemorrhagic fever: an overview. Virol Sin. 2013;28(4):193-201.

10. Pickering LK, Baker CJ, Kimberlin DW, Long SS, eds. Red Book: 2012 Report of the Committee on Infectious Diseases.Elk Grove Village, IL:American Academy of Pediatrics; 2012.

11. Scott LA and Stone MS. Viral exanthems. Dermatology Online Journal 2014;9:4.

12. Schlossberg D. Fever and rash. Infect Dis Clin North Am 1996; 10:101-10.

13. Son MB, Newburger JW. Kawasaki disease. Pediatr Rev. 2013;34(4):151-62. 